\title{
Relationship Between Higher Order Thinking and Metacognitive Skills with Hands-On Teaching Among Primary School Science Teachers in Jempol District
}

\author{
Punnithann Subramaniam, Tajularipin Sulaiman* and Nurzatulshima Kamarudin
}

Faculty of Educational Studies, Universiti Putra Malaysia

\begin{abstract}
Higher order thinking skills and metacognitive skills are essential in generating intellectual competitiveness to meet the challenges of acquiring today's knowledge. This study examines the relationship between higher order thinking skills (HOTS) and metacognitive skills with hands-on teaching in Science among primary school Science teachers in the Jempol district. The purpose of this study is to look at the relationship between the level of higher order thinking skills (HOTS) and metacognitive skills with hands-on teaching in Science among primary school Science teachers in the Jempol district. This study is designed using descriptive and correlation methods. This study uses the quantitative approach by using questionnaire. The findings of the quantitative analysis show that the level of thinking skills is high $(\mathrm{M}=4.36$, S.D. $=0.577)$ among Science teachers in the Jempol district. In addition, the findings show that the metacognitive level was high $(M=4.39$, S.D. $=0.579)$ among Science teachers in the Jempol district. Next, the level of hands-on teaching in Science is high (M = 4.37, S.D. = o.543) among Science teachers in this district. The findings show that there is a significant relationship between higher order thinking skills (HOTS) and hands-on teaching in Science $(\mathrm{r}=0.739, \mathrm{n}=94, \mathrm{p}<$ o.01). This study shows that the relationship between metacognitive and hands-on teaching is stronger. Multiple regression analysis was conducted, and the findings show that the Beta value for metacognitive skills is higher (0.626) compared to the Beta value of higher order thinking skills (HOTS) (0.265). This study will impact science teachers in the Jempol area to focus more on higher order thinking skills (HOTS) and metacognitive teaching.
\end{abstract}

Keywords: Higher Order Thinking Skills, Metacognition, Science hands-on teaching

\section{INTRODUCTION}

The progress of a country is dependent on the mastery of skills and learning by its citizens. With an ineffective education system, a country will be left behind. The education system is a medium responsible for the transmission of knowledge and skills to all individuals. Higher order thinking skills (HOTS) are the abilities to apply knowledge, skills, and values. According to the National Education Philosophy in line with the Malaysian Education Blueprint (MEB), thinking skills are part of the six aspirations that needs to be acquired by every student in order to be competitive at a global stage (MEB 20132025). Thinking skills are crucial, should be practiced in the classroom, and are the keys to a student's success (Nessel \& Graham, 2007).

Higher order thinking and metacognitive skills are important for the production of students capable of competing intellectually in the face of challenges in knowledge acquisition in the future. Higher order thinking skills means generating new ideas, ability to solve problems and taking decisions. Robert Marzano proposed a model

*Corresponding author's e-mail: tajulas@upm.edu.my 
known as Dimension of Learning 1997 where this model is used to develop higher order thinking skills. Our government will be competing internationally especially in the Programme for International Student Assessment (PISA) and Trends in International Mathematics and Science Study (TIMSS) assessments stated in the Malaysian Education Blueprint 2013-2025. The two related terms mentioned above, higher order thinking and metacognitive skills, can be applied in hands-on teaching. A student's learning becomes effective when it is active and they are involved in hands-on activities (Abruscato \& DeRossa, 2010). The focus of hands-on Science activities is the teaching of two essential scientific skills, namely the science process skills and manipulative skills (Sharp et. al., 2002). Science process skills comprises basic and integrated science process skills. Each of these principal skills include several skills that teachers should focus on.

Malaysia underperformed in the study by the International Association for The Evaluation of Educational Achievement (IEA) for the UN Education Index (MOE, 2014). The study placed Malaysia at 98 out of 181 countries. The Programme for International Student Assessment (PISA) measures the literacy rate of students aged 15 years, particularly in Mathematics, Science, and their reading rate. The Trends in International Mathematics and Science Study (TIMSS) measures proficiency levels among international students in Mathematics and Science. The findings of the TIMSS and PISA studies indicate a performance downturn in Science at the lower secondary school level (MOE, 2014) as shown in Tables 1 and 2.

Table 1: Malaysia ranking for the Science subject in the TIMSS study from 1999 to 2011

Trends in International Mathematics and Science Study (TIMSS) Committee for the Science subject

\begin{tabular}{llc}
\hline Year & Rank & $\begin{array}{c}\text { Average } \\
\text { Score }\end{array}$ \\
\hline $\mathbf{1 9 9 9}$ & 22 out of 38 & 492 \\
$\mathbf{2 0 0 3}$ & 20 out of 45 & 510 \\
$\mathbf{2 0 0 7}$ & 21 out of 49 & 471 \\
$\mathbf{2 0 1 1}$ & 32 out of 42 & 426 \\
\hline
\end{tabular}

(Source: MOE, 2014)
Table 2: Malaysia ranking for the Science subject in the PISA study from 2009 and 2012

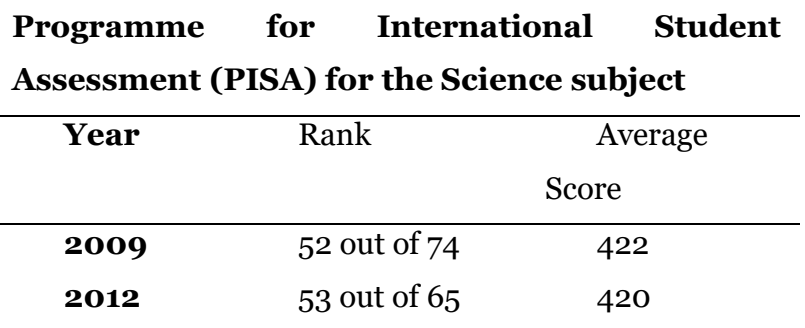

(Source: MOE, 2014)

The majority of schoolteachers still use traditional methods of instruction which are teacher-centred strategies. The use and practice of effective teaching approaches such as the critical method, demonstration, and constructivism are uncommon among Science teachers in our country (Tajularipin Sulaiman \& Nor Azlina Abdul Rahim, 2010). Primary school Science teachers in rural areas incorporate less of the development of higher order thinking skills during teaching and learning activities due to time constraints (Shih Ting Lee, 2009). The lack in application of higher order thinking skills causes students to fail to acquire in-depth understanding of scientific concepts and leads to rote memorization (Chai Jia Yun, 2012). Most science teachers are unable to enhance students' higher order thinking skills as the teachers practice traditional teaching methods (Zainol Budiman, 2008). Students who merely memorize scientific facts and concepts will not have their thinking stimulated (Snyder \& Snyder, 2008). Revell and Wainright (2009) explain that traditional instruction methods can cause drastic decline in a student's concentration levels after the first 20 minutes.

Teachers who do not use metacognitive strategies found that the majority of students are able to excel in answering questions that test the aspect of understanding but the same students are less successful in answering questions that test the aspects of application, synthesis, and evaluation (Farah Aida Sanip, 2015).

Thinking skills are fundamental in the process of educating (Yee Mei Heong et. al., 2011). This study explains that a student that is capable of thinking will be able to influence their methods and effectiveness in learning. Therefore, in order to develop proficiency of the knowledge gained, thinking skills are central.

The teaching and learning process that utilizes handson activities will facilitate students in attaining competent comprehension of Science. The aspects of higher order thinking skills (HOTS) and metacognitive skills will also 
improve a student's mastery in thinking. It is hoped that these methods will empower primary school students to select the Science stream at the secondary school level in order to fulfil the government's aspiration of achieving the 60:40 Science: Arts stream ratio.

\section{MATERIALS AND METHODS}

This study is designed using descriptive and correlation methods. Correlation studies explicate the relationship of two or more variables (Pallant, 2013). In this study, the correlation method was used to investigate the interrelation between higher order thinking skills and metacognitive skills with hands-on teaching among Science teachers. Correlation coefficient values were used to determine weak, intermediate, or strong association among these 3 constructs. This study utilizes a quantitative approach using a questionnaire. The questionnaire of this study is divided into 4 sections. Section A is to collect data regarding the demographic data. Section $\mathrm{B}, \mathrm{C}$ and $\mathrm{D}$ are to evaluate 3 constructs of the study. Three constructs of the study are HOTS, metacognitive and hands-on teaching. The location of data collection for this research is the Jempol district in Negeri Sembilan. The Jempol district is a considerably rural area in Negeri Sembilan. Studies on the execution of teaching and pedagogy are rarely performed in this region. The Subject Average Grade (GPMP) for Science in this district is low. Table 3 below shows the population details of this study.

Table 3: Population details

\begin{tabular}{cccc}
\hline Location & \multicolumn{2}{c}{$\begin{array}{c}\text { Population } \\
\text { Science teachers }\end{array}$} & of \\
\hline & & & \\
Jempol District & Male & $=48$ & \\
$\mathbf{( 5 1}$ & primary & Female & $=87$ \\
schools) & & & \\
\hline & & Total & $=135$ \\
\hline
\end{tabular}

(Source: Primary School Management Sector, Jempol and Jelebu District Education Office, 2016)

The sample consists entirely of Science subject teachers. These 108 samples were selected for this study based on the population of Science teachers in this district. The researchers adopted the simple random sampling technique to select the schools involved in this study.

Data was collected using a questionnaire. The questionnaire utilized a Five-Point Likert Scale and was divided into 4 sections as indicated in Table 4.

Table 4: Questionnaire sections and instrument constructs

\begin{tabular}{ccc}
\hline Section & Details & $\begin{array}{c}\text { Number of } \\
\text { Items }\end{array}$ \\
\hline A & $\begin{array}{c}\text { Demographic } \\
\text { Particulars } \\
\text { B }\end{array}$ & 10 \\
& Higher $\quad$ Order & 30 \\
Chinking Skills & Metacognitive & 30 \\
D & Skills & \\
& Hands-on & 37 \\
& Teaching & 107 \\
\hline
\end{tabular}

Data was directly obtained from 108 Science teachers from 36 schools in the district of Jempol, Negeri Sembilan for this study. The researchers visited each school and distributed the questionnaire to teachers who taught the Science subject. The data collected were categorized into the main constructs. Each construct has its sub construct and the data were categorized according to the constructs.

The framework of this study is as follows:

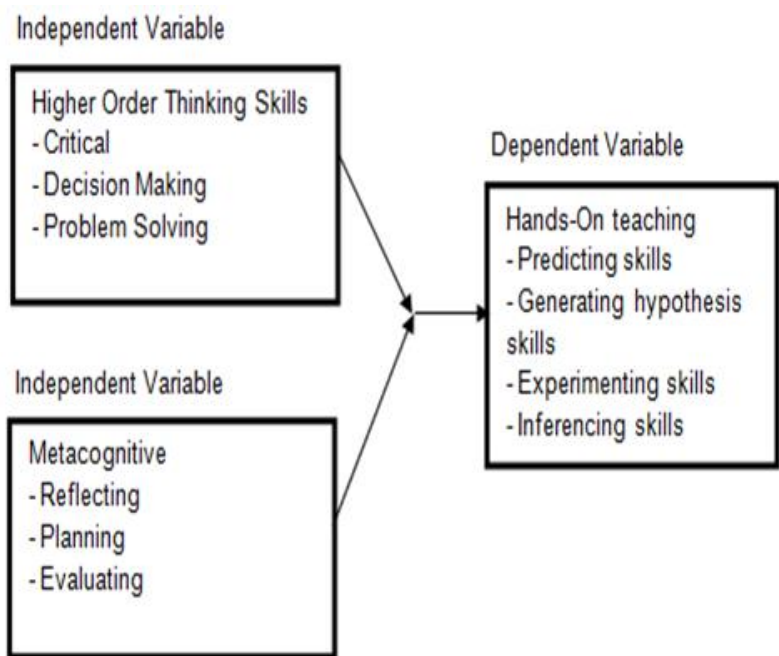

Figure 1 : Framework of the study 


\section{RESULTS AND DISCUSSIONS}

The findings show that 63 respondents (67.0\%) taught at rural primary schools while only 31 respondents (33.0\%) taught at urban primary schools. The findings show that only 27 respondents (28.7\%) were male and the remaining 67 respondents $(71.3 \%)$ were female. The findings show that the respondents were multiracial with 50 respondents (53.2\%) being Malay, 19 respondents (20.2\%) of Chinese ethnicity, and 25 respondents (26.6\%) of Indian ethnicity.

The level of higher order thinking skills among the primary school Science teachers in this study is high with a mean value of $\mathrm{M}=4.36$ (S.D. = 0.577). The Critical subconstruct recorded the highest mean value of $\mathrm{M}=4.40$ (S.D. $=0.558)$. This denotes that the respondents in this study practise critical thinking and is highly committed to being analytical and curious to gain understanding and new knowledge. The Decision-making subconstruct recorded a mean value of $\mathrm{M}=4.32(\mathrm{~S} . \mathrm{D} .=0.624)$ and the Problem-solving subconstruct recorded a mean value of $\mathrm{M}$ $=4.35($ S.D. $=0.620)$.

Table 5: Analysis of the level of higher order thinking skills by subconstructs

Table 6: Analysis of the level of metacognitive skills by subconstructs

\begin{tabular}{llll}
\hline $\begin{array}{l}\text { Metacognitive } \\
\text { Subconstruct }\end{array}$ & N & Mean & $\begin{array}{l}\text { Interpretation/Lev } \\
\text { el }\end{array}$ \\
\hline Reflecting & 94 & 4.38 & High \\
Planning & 94 & 4.43 & High \\
Evaluating & 94 & 4.35 & High \\
\hline Overall & $\mathbf{9 4}$ & $\mathbf{4 . 3 9}$ & High \\
\hline
\end{tabular}

Notes: Mean score range: 1.00-2.33 = Low, 2.34-3.67 = Intermediate, $3.68-5.00=$ High

The findings of this study show that the respondents are highly skilled in Generating Hypothesis which records the highest mean value of $\mathrm{M}=4.38$ (S.D. $=0.542$ ). This denotes that Science teachers in this district are capable of imparting the hypothesis generation skill well through the execution of hands-on teaching.

Table 7: Analysis of the level of hands-on teaching by subconstructs

\begin{tabular}{llll}
\hline $\begin{array}{l}\text { Hands-On } \\
\text { Teaching } \\
\text { Subconstruct }\end{array}$ & N & Mean & $\begin{array}{l}\text { Interpretation/L } \\
\text { evel }\end{array}$ \\
\hline Predicting skill & 94 & $4 \cdot 37$ & High \\
Venerating & 94 & 4.38 & High \\
hypothesis skill & & & High \\
Experimenting & 94 & 4.36 & \\
skill & & & \\
\hline Inferring skill & 94 & $4 \cdot 35$ & High \\
\hline Overall & $\mathbf{9 4}$ & $\mathbf{4 . 3 7}$ & \\
\hline \multicolumn{2}{c}{ Notes: Mean score range: $1.00-2.33=$ Low, 2.34-3.67= }
\end{tabular}
Intermediate, 3.68-5.00 = High

Notes: Mean score range: 1.00-2.33 = Low, 2.34-3.67 = Intermediate, $3.68-5.00=$ High

The level of metacognitive skills among the primary school Science teachers in this study is high with an overall mean value of $\mathrm{M}=4.39$ (S.D. = 0.579). The Planning subconstruct recorded the highest mean value of $\mathrm{M}=4.43$ $($ S.D. $=0.550)$. This denotes that the respondents of this study practises planning in preparation for the execution of hands-on teaching. The Reflecting subconstruct recorded a mean value of $\mathrm{M}=4.38$ (S.D. $=0.568$ ) and the Evaluating subconstruct recorded a mean value of $\mathrm{M}=4.35$ (S.D. = $0.620)$.
Furthermore, analysis of the research findings shows a significant relationship between higher order thinking skills and hands-on teaching $(\mathrm{r}=0.739, \mathrm{n}=94, \mathrm{p}<0.01)$.

Table 8: Correlation between higher order thinking skill subconstructs and overall hands-on teaching

\begin{tabular}{llll}
\hline $\begin{array}{l}\text { Higher Order } \\
\text { Thinking }\end{array}$ Overall Hands- & Level of \\
Subconstruct & On Teaching & Correlation \\
\hline Critical & $\mathrm{r}-0.500^{* *}$ & Strong \\
& $p-0.000$ & \\
Decision-making & $\mathrm{r}-0.633^{* *}$ & Strong \\
& $p-0.000$ & \\
\hline
\end{tabular}




\begin{tabular}{llll}
\hline Problem-solving & $\mathrm{r}-0.804^{* * *}$ & Strong \\
& $p-0.000$ & \\
\hline Overall & Higher & $\mathrm{r}-0.739^{* *}$ & Strong \\
Order & Thinking & $p-0.000$ & \\
Skills & & &
\end{tabular}

Notes: r: 0.10-0.29 = Weak correlation

0.30-0.49 = Intermediate correlation

0.50-1.00 = Strong correlation

Notes: ${ }^{* *}$ Significant at $\mathrm{p}<0.01$

Moreover, analysis of the research findings also shows a significant relationship between metacognitive skills and hands-on teaching $(\mathrm{r}=0.826, \mathrm{n}=94, \mathrm{p}<0.01)$.

Table 9: Correlation between metacognitive subconstructs and overall hands-on teaching

\begin{tabular}{lll}
\hline $\begin{array}{l}\text { Metacognitive } \\
\text { Subconstruct }\end{array}$ & $\begin{array}{l}\text { Overall } \\
\text { Hands-On } \\
\text { Teaching }\end{array}$ & $\begin{array}{l}\text { Level } \\
\text { Correlation }\end{array}$ \\
\hline Reflecting & $0.773^{* *}$ & Strong \\
& 0.000 & \\
Planning & $0.643^{* *}$ & Strong \\
& 0.000 & \\
Evaluating & $0.717^{* *}$ & Strong \\
& 0.000 & \\
\hline Overall & $0.826^{* *}$ & Strong \\
Metacognitive & 0.000 & \\
Skills & & \\
\hline
\end{tabular}

Notes: r: 0.10-0.29 = Weak correlation

0.30-0.49 = Intermediate correlation

0.50-1.00 $=$ Strong correlation

Notes: ${ }^{* *}$ Significant at $\mathrm{p}<0.01$

In conclusion, the findings show a significant relationship between higher order thinking and metacognitive skills with hands-on teaching. The researchers reject both null hypotheses with evidence that there is significant relationship between higher order thinking and metacognitive skills with hands-on teaching among Science teachers in the Jempol district. Both hypotheses also have high correlation levels. The correlation between metacognitive skills and hands-on teaching is stronger than higher order thinking skills.

\section{SUMMARY}

The effort to cultivate higher order thinking and metacognitive skills is arduous as it requires the application of various skills such as critical thinking, decision-making, problem-solving, reflecting, planning, and evaluating. Consequently, the researchers are of the opinion that there is a necessity to increase and reinforce the quality of teachers, especially in honing the abovementioned skills in order to accomplish effective handson teaching. The researchers hope that this study can open the eyes and minds of teachers to the importance of higher order thinking skills and metacognitive skills in hands-on teaching in order to promote a culture of practising higher order thinking among students as well as among the teachers themselves. To ensure the effectiveness in executing higher order thinking skills and metacognitive skills in hands-on teaching, teachers require motivation and guidance in higher order thinking and metacognitive activities before they are able to apply them in teaching students (Barrow, 2006).

\section{ACKNOWLEDGEMENT}

The author would like to express appreciation to the supervisory committees for providing guidance and advice throughout the research process. The authors would like to express sincere gratitude to University Putra Malaysia for funding this research and for providing supervisory support. 


\section{REFERENCES}

Abruscato, J.\& DeRossa, D.A. 2010, Teaching Children Science: A Discovery Approach (7th ed). Boston: Allyn \& Bacon.

Chai Jia Yun. 2012, Effects of Using Hands-on Activities in Year 3 Science Classroom. IPG KBL Action Research Seminar Proceedings, vol3o, no 12, pp.165-179.

Farah Aida binti Sanip. 2015, Awareness Evaluation on Metacognitive Strategy and Higher Order Thinking Skills Among Biology Students. Malaysia Educational Journal, vol 7, no 23, pp. 10-42.

Jempol and Jelebu District Education Office. 2016, Science Teachers List. Negeri Sembilan: Primary School Management Sector.

Ministry of Education. 2014, Higher Order Thinking Skills. Kuala Lumpur: Ministry of Education.

Nessel, D.D.\& Graham, J.M. 2007, Thinking Strategies for Student Achievement: Improving Learning Across the Curriculum, K-12 (2nd ed.). Thousand Oaks, California: Corwin Press.

Pallant, J. 2013, SPSS Survival Manual: A Step by Step Guide to Data Analysis Using SPSS (5th ed.). England: McGraw Hill.

Revell, A. \& Wainwright, E. 2009, What Makes Lectures 'Unmissable'? Insights into Teaching Excellence and Active Learning. Journal of Geography in Higher Education, vol 33, no 2, pp. 209-223.

Sharp, J., Graham, P., Johnsey, R., Simon, S., \& Smith, R. 2002, Primary Science: Teaching Theory and Practice, Exeter: Learning Matters.

Snyder, L.G.\& Snyder, M.J. 2008, Teaching Critical Thinking and Problem-Solving Skills. The Delta Pi Epsilon Journal, vol 2, no 10, pp. 90-99.

Tajularipin Sulaiman \& Nor Azlina Abdul Rahim. 2010, Various Approaches In Teaching Science Effectively. University Putra Malaysia: UPM Publisher.

Yee Mei Heong, Jailani Md Yunos, Widad Othman, Razali Hassan \& Tee Tze Kiong. 2011, Application of Marzano's Higher Order Thinking Skills in Generating Ideas. University Tun Hussein Onn Educational Journal, vol31, no 2, pp. 21-39.

Zainol Badli Budiman. 2008, Development of Cognitive Conflict Module and Its Effect on Cognitive
Development and Science Achievement. Doctoral dissertation, National University of Malaysia, Bangi, Selangor. 